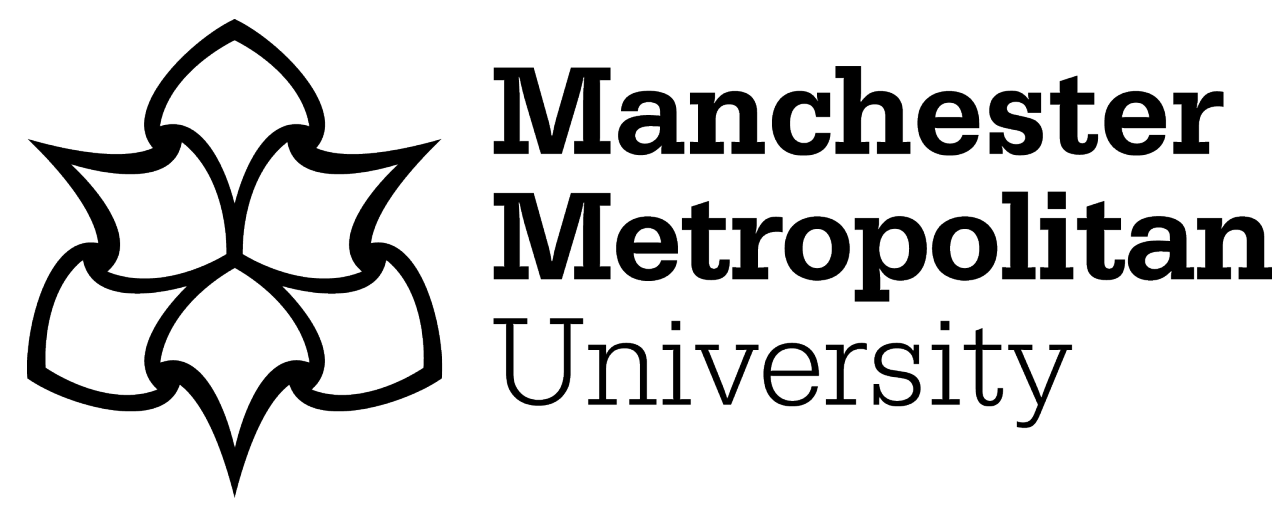

Cookney, Daniel ORCID logoORCID: https://orcid.org/0000-0002-0060-4969 (2019) The Architecture of Underground Dance Music: The Work of Shaun Bloodworth. Architecture and Culture, 7 (2). pp. 235-247. ISSN 2050-7828

Downloaded from: https://e-space.mmu.ac.uk/629084/

Version: Accepted Version

Publisher: Informa UK Limited

DOI: https://doi.org/10.1080/20507828.2019.1614799

Please cite the published version 


\title{
The Architecture of Underground Dance Music: The Work of Shaun Bloodworth \\ Daniel Cookney
}

\section{Author biography:}

Daniel Cookney is an educator and designer with transdisciplinary interests. His research and practice work has explored a number of areas of communication design although a notable specialism is within the performance of identity - particularly in the music industry. As a writer, he additionally contributes to a number of print and online publications and is co-editor of Music/Video: Histories, Aesthetics, Media.

\begin{abstract}
:
This photo essay presents a posthumous consideration of the work of Shaun Bloodworth, photographer of musicians from the UK underground dance scene in the early twenty-first century. It argues that Bloodworth sets up in his portraits a connection between figure and background that involves the same re-territorialization of the urban landscape that occurred in the dance scene itself in the late 1980s, when dance music promoters illegally occupied dilapidated unused spaces for parties in cities such as Sheffield, London and Manchester. The catalog of work that Bloodworth left on his death in 2016 can be seen as a series of images which play on a tension between anonymity and celebrity, both of the musicians and of the architectural setting.
\end{abstract}

Image captions:

Figures $1 \&$ 2: Portraits of Skepta by Shaun Bloodworth, 2008

Figure 3: Portrait of Horsepower Productions by Shaun Bloodworth, 2010

Figure 4: Portrait of Mary Anne Hobbs by Shaun Bloodworth, 2010

Figure 5: Portrait of Hudson Mohawke by Shaun Bloodworth, 2009

Figure 6: Portrait of Jacques Greene by Shaun Bloodworth, circa 2014

Figure 7: Portrait of The Black Dog by Shaun Bloodworth, 2013

Figure 8: Portrait of Silkie \& Quest by Shaun Bloodworth, 2012. 


\section{The Architecture of Underground Dance Music: The Work of Shaun}

\section{Bloodworth}

\section{Introduction}

In September 2016, Shaun Bloodworth passed away while awaiting a liver transplant. Prior to his hospitalisation, he had gained a reputation as a photographer documenting makers of electronic dance music in urban settings. His location-based approach to image-making may have been a necessity: Bloodworth didn't possess a studio of his own, and the post-production involved in his photographic output was often carried out at his kitchen table. He used this limitation to configure a notable kinship between his subjects and their architectural backdrops, resulting in composites of figure and ground that, despite being rooted in the tradition of portraiture, require each element to maintain a semblance of anonymity.

Bloodworth's work has a kind of iconoclastic fetishism. Like the music it promotes, its determined refusal of personality is intended to "deconstruct ... the function of the author." ${ }^{1}$ His images overtly identify the makers of electronic dance music as "anonymous," even in cases where aspects of their identities - such as their real names - are publicly known. Both they and their environments are made to appear generic. David Hesmondhalgh claims that the underground dance music industry's rejection of personality and of a "star system" is in order to concentrate attention on "the music itself," without the distraction of a biographical back-story. ${ }^{2}$

The demand that we should focus on "the music," rather than anything deemed extraneous to it, is not new, nor is it specific to any particular musical genre. Almost 90 years ago, critic Lionel McColvin called for "anonymity in music," complaining that "it is fairly certain that a stranger to music would believe, after surveying our present conditions, that the performer was far more important than the music he

\footnotetext{
${ }^{1}$ Brian L. Ott and Bill D. Herman, "Mixed Messages: Resistance and Reappropriation in Rave Culture," in Western Journal of Communication, 67:3 (2003): 205.

${ }^{2}$ David Hesmondhalgh, "The British Dance Music Industry: A Case Study of Independent Cultural Production," in British Journal of Sociology, 49(2) (1998), 234.
} 
performed." 3 The unease over any cult of the individual artist - whether in music or in other creative disciplines - was and is in order to further "the art as an ideal, not the ego." 4 Bloodworth's work addresses these concerns head-on. He elects to promote the music through portraits of its performers, yet the way he constructs these portraits, and the emphasis he gives to their carefully chosen architectural settings, serves to suppress the personality of the artist.

\section{Skepta}

\section{(Figures 1 and 2 near here)}

Two portraits of electronic music-maker Skepta were taken by Bloodworth in 2008 to accompany the fourth instalment of Rinse FM's Rinse Mix Series, a new release from the roster of what was initially an illegally-broadcasting radio station. The profile view was used as a press shot, the frontal view as the artwork for the release itself, but they work together as a diptych - one which evokes the standardized "mugshots" developed at the beginning of the twentieth century by statistician Alphonse Bertillon to document criminal character. ${ }^{5}$ In this way, Skepta is presented simultaneously as a particular object of fascination and as a generic criminal type (perhaps hinting at Skepta's, and Rinse's, own origins). The background of riveted galvanized metal sheets, suggesting the boarding-up of something - possibly a once-utopian social housing scheme - may also be a nod to the pirate radio station's source in the forgotten spaces of London's council estates.

Bloodworth uses this textured urban backdrop, together with de-saturated color, across the Rinse Mix Series as a whole, to provide what he described as "a uniform

\footnotetext{
${ }^{3}$ Lionel R. McColvin, "Anonymity in Music," in The Musical Times, vol. 71, no. 1046 ( $1^{\text {st }}$ April 1930), 317. Available online at: http://www.jstor.org/stable/914492 (accessed 20th March 2018).

${ }^{4}$ Henry Hazlitt, "The Cult of Anonymity," in Nation, Oct 30, 350 (1930), quoted in Anne Ferry, "Anonymity: The History of a Word," in New Literary History, vol.33, no.2, Anonymity, pp.193-214 (2002), 198.

${ }^{5}$ The 'mugshot' itself was developed at the same time as statistics was starting to be used: then allowing recorded, individual data to be compared in order to better understand generic types. It is associated with criminality not only because the person can be identified, but also because their traits can be compared to those of hundreds of others, in the search for a 'criminal type'.
} 
feel." ${ }^{\prime 6}$ Both portrait and background are in the same tone, bluring distinction between the two; Skepta becomes part of his unloved setting. If the genre of "grime" (to which Skepta's music belongs) is the UK's home-grown version of hip hop, then the cold, hard glimpse of a "failed" location marks grime's refusal of hip hop's fascination with "aspirational lifestyle" or the kind of success that equates with wealth. What the portrait isn't helps to define what it is, and thus to establish the place of Skepta and Rinse within a taxonomy of music and media. Will Straw writes that:

Ideas of authorship are bound up with the commodity status of music in a variety of ways. It is not simply that the performer becomes the hook through which musical performances are given distinctiveness and marketed (as "stars" have long served to differentiate films). Over the long term, the continuity of performer careers is seen as a way of bringing order to the musical marketplace by introducing a particular kind of predictability. The identities of performers help the music industries to plan the future, to see this future as a sequence of new releases that will build upon (and draw their intelligibility from) the activity of the past. $^{7}$

In the case of the Rinse Mix Series images, where conventional "star" photography is eschewed for a greyed-out palette both defined by and incorporating the inner-city landscape, the version of authorship that is communicated is that of the street-smart citizen who literally blends in with his background, but whose apparently effortless "rawness" signals confidence, even authority.

\section{Horsepower Productions}

(Figure 3 near here)

Bloodworth's borrowing of the warehouse as the setting for his portrait of Horsepower Productions, that was subsequemtly cropped as artwork for a FACT mix in 2010, appears unremarkable. After all, such spaces are commonplace. While in desirable areas, gentrification may have sold industrial buildings as "loft living," less fashionable parts of town still boast these poorly-lit relics that, at best, find some use

\footnotetext{
${ }^{6}$ Danna Takako, "Eye Candy: Shaun Bloodworth and Stuart Hammersley," Fabric Blog, (2010). Available at: https://www.fabriclondon.com/blog/view/eye-candyshaun-bloodworth-stuart-hammersley Accessed: 24/02/17.

${ }^{7}$ Will Straw, "Authorship," in Key Terms in Popular Music and Culture, eds. B. Horner and T. Swiss, pp.109-208 (Oxford: Blackwell, 1999), 203.
} 
as car parks. But there is a specific connection of such spaces with electronic dance music, something that Nav Haq refers to in his discussion of "the rave movement:"

Part of the socio-economic conditions that led us to the advent of the rave movement was due to [...] the decline of industrialism [...]. Many [...] post-industrial cities, such as Detroit, Manchester and Sheffield, subsequently became important centres for electronic music. In these areas of high unemployment, rave culture for young people opened up an alternative space for working-class unification. Many former industrial buildings were utilised for rave and freeparties, with some also becoming nightclubs. For some commentators, the former industrial landscape was also echoed in the repetitive machine music being produced in those places, including the industrial techno subgenre. ${ }^{8}$

Warehouse parties gained exposure in London when associated with the dance movement based around "rare groove" in the mid 1980s; in subsequent years they became more closely linked with the culture that followed the development of "acid house." Their "derelict locations [...] with their dusty floors and industrial ambience, offer only crumbling walls, a loud sound system, and the potential for anything to happen," wrote Sivan Lewin; "unpredictable and unrestrained, the parties are imbued with the thrill of their dubious legality." 9 The term "house music," forebear of acid house and rave, is directly derived from The Warehouse, a Chicago nightclub that opened in 1977, and was the first to champion what was introduced as a stripped-back disco mutation. Hillegonda Rietveld, who sees The Warehouse as the blueprint for later developments in the UK, observes that its downtown site was "away from any mainstream leisure area of Chicago," something echoed in the UK's rave scene's approach to "authentic" location. ${ }^{10}$ In Manchester, The Hacienda nightclub of the

\footnotetext{
${ }^{8} \mathrm{Nav}$ Haq, Rave and Its Influence on Art and Culture (London: Black Dog Publishing, 2016), 31.

${ }^{9}$ Lewin, Sivan. (1997). "Loft Cause," in Night Fever: Club Writing in The Face, ed.

R. Benson (London: Boxtree, 1997), 89-90.

${ }^{10}$ Hillegonda Rietveld, This Is Our House: House Music, Cultural Spaces and Technologies (Aldershot: Ashgate, 1998), 18. See also Jeremy Gilbert and Ewan
} 
1980s appeared to mirror Chicago's Warehouse. Central but off-centre, a disused yacht-builder's workshop in a then un-glamorous part of the city, it was repurposed by Factory Records as one of the first UK clubs to play house music. ${ }^{11}$

The entrepreneurial, opportunistic approach to occupying the abandoned spaces of a city in decline has a covert, subversive quality that also characterizes Bloodworth's work; "there's a lot of mischief and darkness in electronic music and I'm drawn to that," he said. ${ }^{12}$ In his portrait, the four members of the Horsepower Productions team stand uneasily in the vast emptiness of the building, staring straight at the camera. Despite their determinedly calm expressions and solidly planted feet, it's hard not to see something furtive and defiant in their attitude. The warehouse, specific yet anonymous (it's in London's now ultra-trendy Shoreditch), functions as a reminder that, for communities defined by the decimation of industry, the take-over of industrial settings for recreational purposes was a genuine and viable alternative to mainstream commercial entertainment. The fact that it was illicit only helped to give "credibility to dance music scenes." 13

\section{Mary Anne Hobbs}

(Figure 4 near here)

Bloodworth's portrait of DJ and electronic music-maker and promoter Mary Anne Hobbs, made in 2011, displays a fully explicit disjuncture between figure and ground. There is "a real sense of deliberately setting up a juxtaposition between Mary Anne in that elegant white dress [and the unforgiving industrial environment]," says long-time Bloodworth collaborator Stuart Hammersley. ${ }^{14}$ Through Hobbs's careful poise in her pristine, sculptural garments and prominent high heels, hands held awkwardly outwards, Bloodworth configures his subject as a deliberate, self-conscious alternative

Pearson, Discographies: Dance Music, Culture and the Politics of Sound (London: Routledge, 1999), 23.

${ }^{11}$ Factory Records employed designer Ben Kelly to renovate the building, in such a way that its industrial detailing would be celebrated.

12 Takako, "Eye Candy: Shaun Bloodworth and Stuart Hammersley," online.

${ }^{13}$ John Connell and Chris Gibson, Sound Tracks: Popular Music, Identity and Place. (London: Routledge, 2003) 204.

${ }^{14}$ Stuart Hammersley in interview with the author (2017). 
to the setting, rather than as its continuation, as is more typical in his work. The DJ seems equal to her dark, chaotic surroundings, not by blending in but by standing out.

The location itself is the vast Forgemasters manufacturing plant in Sheffield. The connection Haq's cites between former industrial production and the production of electronic music seems as apt in this famed "Steel City," with its predilection since the 1980s for machine-driven, automated music as it is in techno-capital Detroit, former home of the automobile industry. For Sheffield musician Martin Dust of production unit The Black Dog - its tracks familiar on Hobbs's playlists - the sound of the machines was not just a formative influence, it was intrinsic to the music. "For many of us, it lulled us to sleep at night," he says. ${ }^{15}$

\section{Hudson Mohawke}

\section{(figure 5 near here)}

The portrait of producer Hudson Mohawke formed part of the North/South/East/West project instigated by Bloodworth and Hammersley, which resulted in 2009 in a compilation album of electronic music sourced from makers from disparate geographical locations. The photographic component of the album showed the individuals involved each in their hometowns, already associating them with their settings.

“There are some shots we took in LA," says Hammersley.

"For example, with Dam Funk who we arranged to meet in the parking lot of an abandoned shopping mall [...] The Hudson Mohawke picture was a stroke of luck really. Shaun spotted the lightwell of the building next to the hotel where we were staying in Glasgow and saw it as a great spot to shoot. We paid a tenner to a window cleaner to borrow his ladder to all climb down into it and took a few shots". 16

The space clearly isn't designed to be accessible, its original function being simply to let light into the basement floor of the building of which it is nominally a part. But its discreet location, below street level, has allowed it to acquire new uses. It is now

\footnotetext{
${ }^{15}$ Martin Dust in interview with the author (2017).

${ }^{16}$ Stuart Hammersley, interview with the author, 2017
} 
home to an air conditioning unit, and acts as a receptacle for discarded styrofoam cups; Mohawke's own will be added shortly. Cups and AC unit, and Mohawke's pallid skin, show up white against the grimy sandstone, transient elements against its solidity. The space tolerates them but does not welcome them. The location is like a strangely domesticated, cell-like version of one of Marc Augé's non-places, in which "the fleeting, the temporary and ephemeral" briefly seem to settle. ${ }^{17}$

\section{Jacques Greene}

(figure 6 near here)

Locations that are both forgotten spaces and places of potential imprisonment within a city grown disordered become, for Bloodworth, signifiers of a defiant disenfranchisement. As with the Hudson Mohawke photograph, the portrait of Canadian musician Jacques Greene invites the viewer to construct a narrative of how we may have arrived at this scene - though in this case we are without Hammersley's description. Here, the stonework is replaced by metal. Corrugated site hoardings and temporary fencing, padlocked together, hide the figure in full view, trapped by the alienating upheavals of endless neoliberal "regeneration."

But it is not entirely clear whether Greene is prisoner or trespasser. He hovers, hands in pockets, in a place that is clearly out of bounds. Martin Dust suggests that the appropriation of these spaces, like that of the rumbling sound of the machines, is not just aesthetic: "for many of us, as children, these are the places we played or hung out," he says. ${ }^{18}$ It's not just the space that is in some sense reclaimed in Bloodworth's photograph, but also a childhood. ${ }^{19}$

\section{The Black Dog}

(figure 7 near here)

\footnotetext{
${ }^{17}$ Marc Augé, Non-Places: An Introduction to an Anthropology of Supermodernity (London: Verso, 1995), 78.

${ }^{18}$ Martin Dust in interview with the author (2017).

${ }^{19}$ This reclamation for childhood recreation recounts the development of the original adventure playgrounds - post-World War II bomb sites - before they became subject to health and safety audits. But there is a difference in the kind of abandoned place: one is the result of wilful wartime destruction, the other of neglect. See, for example, Stephen Willats' 'The Lurky Place' (1978).
} 
All of these images of Bloodworth's can be seen as reterritorializations of "no man's land." The underpass, a setting he has used for a number of different shoots, is a particularly potent example: a public space that, in the UK at least, is often a no-go area. It has developed a relationship with anti-social behaviour; poorly frequented, hidden from view, underpasses are considered to be dangerous thoroughfares, places of potential entrapment or illicit activity. Stanley Kubrick notoriously cemented these perceptions in his 1971 film adaptation of $A$ Clockwork Orange, which made images of these municipal routes within heroic residential suburbs a visual shorthand for dystopia. Movies such as Daniel Barber's Harry Brown of 2009 have capitalized on this association with domesticated menace. The underside of brutalist functionalism offers an untidy, negative inversion of infrastructure that appears the obverse of the purported safety and security of home.

Bloodworth has returned to the underpass, with its suggestion of delinquent occupation, for press pictures of the Black Dog group as well as of electronic music producers such as Blawan and Joker. But he has not tried to create a typology of underpasses, as Bernd and Hilla Becher might have done. In the Bechers' work we are presented with numerous examples of a "type," so that we are compelled to acknowledge their specific differences. Bloodworth uses underpasses in a different way each time - he captures them from different angles, at different scales and with different points of focus - but the sense of them remains the same, so that we recognize instead their interchangeability, their very unremarkableness. They are twilight settings in a twilight zone, somewhere between "underground" and "street," the very locations where the electronic music scene can be found, lurking.

\section{Silkie \& Quest}

\section{(figure 8 near here)}

The space beneath the overpass may, by contrast, seem less threatening. There's more natural light, more air (albeit full of traffic fumes), less fear of a dead end. But Bloodworth chooses examples which are still claustrophobic, hemmed in. Borders are established by concrete fence posts and barbed wire, in some haphazard arrangement outside the order of the city; this is where figures come together, trapped yet defiant. These places are hardly prime real estate. Should we look to find them on a map, they will be invisible, hidden beneath the logic of the motorway network. 
In Bloodworth's 2012 portrait of mixers Silkie and Quest, the slick "statement architecture" glimpsed in the distance (the Hammersmith Ark in West London) only draws attention to the other, less glossy, elements of the composition - the underside of the flyover and a towering blank wall, elements that Hammersley describes as simply "the ordinary and the everyday." ${ }^{20}$ Bloodworth's subjects here seem to blend in with the setting, fully at home in these bleaker corners of the metropolis. Hammersley talks about how the photo shoots took place:

There was no styling, hair and make-up, intricate lighting involved in any of those shoots that we did together. Nine times out of ten it would just be me, Shaun and his camera. One maybe two lights, and then the subject [...]. We weren't into constructing some fantastic, alternate reality in the shots. ${ }^{21}$

Yet there is still a constructed image there. Bloodworth's portraits repeatedly set up a dialogue between figure and setting that is part antagonistic (his figures almost always look uneasy) and part a kind of transference of meaning (the environment speaks of its occupants, and vice versa). We are made acutely aware of both figure and background, as each informs and enriches the other. Both figures and settings become clearly visible as types, so generic that they are starkly recognizable - so generic that their haunting character shows through. Bloodworth once said of his own hometown of Sheffield that it was "slightly downtrodden on the surface but has world quality underneath". ${ }^{22}$ His work makes us see both aspects in all his subjects, places and people.

\section{References}

\footnotetext{
${ }^{20}$ Stuart Hammersley in interview with the author (2017).

${ }^{21}$ Stuart Hammersley in interview with the author (2017).

${ }^{22}$ Anon., "Shaun Bloodworth." Sheffield Culture Guide, (n.d.). Available at http://www.ourfaveplaces.co.uk/info/contributors/shaun-bloodworth Accessed: 24/02/17.
} 
- Anon. n.d. "Shaun Bloodworth." Sheffield Culture Guide. Available online: http://www.ourfaveplaces.co.uk/info/contributors/shaun-bloodworth (accessed 24 February 2017).

- Aug_e, Marc. 1995 [1992]. Non-Places: Introduction to an Anthropology of Supermodernity, translated by John Howe. London: Verso.

- Barber, Daniel, dir. 2009. Harry Brown.

- Connell, John, and Chris Gibson. 2003. Sound Tracks: Popular Music, Identity and Place. London: Routledge.

- Ferry, Anne. 2002. “Anonymity: The History of a Word.” New Literary History 33, no. 2: 193-214.

- Gilbert, Jeremy, and Ewan Pearson. 1999. Discographies: Dance Music, Culture and the Politics of Sound. London: Routledge.

- Haq, Nav. 2016. Rave and Its Influence on Art and Culture. London: Black Dog Publishing.

- Hazlitt, Henry. 1930. "The Cult of Anonymity.” Nation (30 October).

- Hesmondhalgh, David. 1998. "The British Dance Music Industry: A Case Study of Independent Cultural Production.” British Journal of Sociology 49, no. (2): 234-51.

- Kubrick, Stanley dir. 1971. Clockwork Orange.

- Lewin, Sivan. 1997. "Loft Cause." In Night Fever: Club Writing in The Face, edited by R. Benson, 89-90. London: Boxtree.

- McColvin, Lionel R. 1930. “Anonymity in Music.” The Musical Times 71, no. 1046 (1 April): 317-18. Available online: http://www.jstor.org/stable/914492 (accessed March 20, 2018).

- Ott, Brian L., and Bill D. Herman. 2003. "Mixed Messages: Resistance and Reappropriation in Rave Culture." Western Journal of Communication 67, no. 3: 249-70.

- Rietveld, Hillegonda. 1998. This Is Our House: House Music, Cultural Spaces and Technologies. Aldershot: Ashgate.

- Straw, Will. 1999. “Authorship.” In Key Terms in Popular Music and Culture, edited by Bruce Horner and Thomas Swiss, 199-208. Oxford: Blackwell.

- Takako, Danna. 2010. "Eye Candy: Shaun Bloodworth and Stuart Hammersley." Fabric Blog. https://www.fabriclondon.com/blog/view/eye-candy-shaun-bloodworthstuart-hammersley (accessed February 24, 2017).

- Willats, Steven. 1978. The Lurky Place. London: Lisson Gallery. 
